\title{
POTENSI PUPUK HIJAU TURI MINI (Sesbania rostrata Brem) DALAM BIDANG PERTANIAN
}

\section{POTENTIAL OF GREEN MANURE ROSTRATE SESBANIA (Sesbania rostrate Brem) IN AGRICULTURE}

\author{
Fitri Kurniati ${ }^{1}$ \\ ${ }^{1}$ Program Studi Agroteknologi Fakultas Pertanian Universitas Siliwangi \\ Jl. Siliwangi No 24 Kota Tasikmalaya
}

Korespondensi : fitri.kurniati61@gmail.com

\begin{abstract}
ABSTRAK
Penggunaan pupuk anorganik yang terus menerus menyebabkan kerusakan tanah dan pencemaran lingkungan akibat residu yang ditinggalkannya. Penggunaan pupuk organik dapat mengatasinya dengan cara meningkatkan kesuburan fisik, kimia dan biologis tanah. Salah satu diantaranya adalah pupuk hijau yang sekaligus mengatasi masalah keterbatasan pupuk organik yang berasal dari pupuk kandang. Pupuk hijau yang potensial untuk dikembangkan adalah turi mini (Sesbania rostrata) dari kelompok legum yang mempunyai beberapa kelebihan dibandingkan legum lainnya. Turi mini mempunyai nodula pada batang yang sangat banyak, selain pada akarnya, yang bekerjasama dengan bakteri Azorhizobium caulinodans untuk menambat $\mathrm{N}_{2}$ udara. Jumlah nodul itu bisa 5 sampai 10 kali lipat daripada legum lainnya, sehingga dapat memfiksasi $\mathrm{N}_{2}$ udara mencapai 5 sampai $10 \mathrm{kali}$ lipat yaitu $270 \mathrm{~kg} \mathrm{ha}^{-1}$. Turi mini dapat meningkatkan efisiensi penyerapan $\mathrm{N}$ sampai $25 \%$, meningkatkan kandungan $\mathrm{N}$ tanah dan meningkatkan penyerapan P. Kelebihan dari legum lain adalah mampu hidup pada kondisi tergenang seperti di rawa-rawa atau pada lahan sawah, tahan terhadap tingkat salinitas tinggi, tahan terhadap kekeringan. Hasil penelitian yang telah dibuktikan beberapa peneliti adalah meningkatkan hasil gabah padi, meningkatkan bobot tongkol jagung dan mengurangi penggunaan pupuk anorganik urea.
\end{abstract}

Kata kunci: efisiensi, pupuk hijau, turi mini

\begin{abstract}
Using anorganic fertilizer continuously cause the soil damage and environment pollution because their residue. Using organic fertilizer can resolve by increase physical fertility, chemical fertility and biological fertility. One of them is green manure that can overcome limiting of the other manure. Green manure that potential to be developed is rostrate sesbania (Sesbania rostrata), the one of leguminoceae, that has several advantages than the other legume. Rostrate sesbania has many nodule in the stem, beside root nodule, that symbiosis with Azorhizobium caulinodans to $\mathrm{N}_{2}$ fixation. The number of rostrate sesbania nodule 5 to 10 times so can fixation 5 to 10 times, that is $270 \mathrm{~kg} \mathrm{ha}^{-1}$ nitrogen. Rostrate sesbania can increase efficiency of $\mathrm{N}$ uptake until $25 \%$, increase soil $\mathrm{N}$ and increase $\mathrm{P}$ uptake. The advantage rostrate sesbania than the other legume can be able to live in the waterlogging like swamp or rice low land, resisten to soil salinity, and drought. The result of the experiment of several researchers, rostrate sesbania increase the rice yield, increase the corncob, and decrease using anorganic fertilizer.
\end{abstract}

Key words : efficiency, green manure, Rostrate sesbania 


\section{PENDAHULUAN}

Upaya meningkatkan produksi pertanian seringkali dikaitkan dengan meningkatkan pemupukan. Menurut Sumarno et al. (2000), usaha pertanian modern pada umumnya mengutamakan pemacuan sumberdaya lahan dengan menggunakan sarana produksi anorganik yang berasal dari luar agroekosistem pertanian. Dikatakan Simanungkalit (2006), bahwa pemberian pupuk anorganik merupakan cara yang paling efektif untuk memenuhi kebutuhan hara esensial bagi tanaman. Sehingga petani lebih suka menggunakan pupuk anorganik daripada pupuk organik. Pupuk anorganik sudah menjadi kebutuhan dasar, terutama bagi varietas unggul padi yang sangat responsif terhadap pupuk. Terindikasi bahwa dengan adanya kasus kelangkaan pupuk anorganik yang sering terjadi di Indonesia, telah membuat panik para petani.

Di sisi lain, penggunaan pupuk buatan secara terus menerus dan dalam jumlah besar tidak hanya menambah besarnya biaya produksi, tetapi juga berdampak negatif pada lahan yang diusahakan. Dikatakan Haryanto et al. (2004), bahwa pemberian pupuk kimia terus menerus pada lahan sawah akan menyebabkan bertambahnya degradasi bahan organik dan penurunan potensi jasad renik yang berperan dalam penyediaan hara tanah, sehingga produktivitas lahan akan menurun.

Berdasarkan penelitian Abdurachman (2004), pemupukan jangka panjang di Kebun Percobaan Sukamandi, Jawa Barat menunjukkan bahwa pemberian pupuk NPK selama 25 musim tanam menyebabkan penurunan hasil padi varietas IR36, namun belum nampak pada varietas IR64 yang ditanam selama 8 musim. Penurunan hasil disebabkan menurunnya kandungan bahan organik tanah yang menyebabkan menurunnya kemampuan tanaman padi untuk membentuk anakan.
Kualitas lingkungan akan mengalami penurunan akibat pengggunaan pupuk anorganik yang terlihat dari residu kimia pada hasil panen dan juga cemaran pada air (Simanungkalit, 2006). Menurut Hapsari (2011), pertanian pada lahan sawah yang menggunakan pupuk anorganik secara terus menerus dapat merusak kesuburan tanah, sedangkan praktek pertanian organik dapat menghasilkan pangan secara berkesinambungan dan tidak merusak kesuburan tanah serta menyediakan bahan organik tanah.

Pupuk anorganik yang seringkali digunakan petani adalah urea sebagai sumber nitrogen, SP36 sebagai sumber fosfor dan $\mathrm{KCl}$ sebagai sumber kalium, atau menggunakan NPK sebagai sumber ketiga unsur hara makro tersebut sekaligus. Pertimbangan penggunaan NPK adalah mengefisienkan tenaga kerja pemupukan.

Selain pada tanaman padi, pupuk anorganik juga digunakan pada tanaman palawija, misalnya jagung manis. Jagung manis menghendaki nitrogen yang cukup tinggi untuk meningkatkan kandungan klorofil. Seperti dikatakan Vanyine et al. (2012), bahwa peningkatan dosis pupuk nitrogen dapat meningkatkan kandungan klorofil daun secara signifikan. Kemudian terdapat korelasi postif antara kandungan klorofil daun dengan kandungan protein biji pada tanaman jagung. Dengan demikian penambahan nitrogen ke dalam tanah dapat memperbaiki komponen hasil pipilan jagung.

Menurut Koswara (1992) dalam Effendy et al. (2020), pupuk yang direkomendasikan untuk tanaman jagung manis adalah pupuk anorganik urea $435 \mathrm{~kg} \mathrm{ha}^{-1}$, TSP 150 $\mathrm{kg} \mathrm{ha}^{-1}$, dan KCL $150 \mathrm{~kg} \mathrm{ha}^{-1}$. Sedangkan hasil penelitian Mathuika et al. (2014) menunjukkan bahwa hasil jagung yang tinggi diperoleh dengan perlakuan pemupukan $\mathrm{N} 120 \mathrm{~kg} \mathrm{ha}^{-1}$ dan $\mathrm{P}_{2} \mathrm{O}_{5} 60 \mathrm{~kg} \mathrm{ha}^{-1}$ pada jarak tanam $45 \mathrm{~cm} \times 20 \mathrm{~cm}$ di daerah Selatan Gujarat. 
Menurut Fahmi et al. (2010) dalam Hidayati dan Armaini (2015), hara nitrogen dan fosfor merupakan hara yang dibutuhkan oleh tanaman dalam jumlah besar yang berfungsi dalam pembentukan klorofil, protoplasma, protein, dan asam inti. Dikemukakan juga oleh Suwardi dan Efendi (2009), bahwa pemberian nitrogen (N) yang tidak seimbang dengan kebutuhan tanaman baik jumlah maupun waktu pemberiannya akan menyebabkan kehilangan $\mathrm{N}$ dalam tanah, pertumbuhan tanaman yang tidak optimal dan pada akhirnya menyebabkan rendahnya efisiensi penggunaan $\mathrm{N}$.

Selanjutnya dikatakan Wahid (2003), bahwa pemberian pupuk $\mathrm{N}$ yang berlebihan, selain akan memperbesar biaya produksi juga akan merusak lingkungan akibat adanya emisi gas $\mathrm{N}_{2} \mathrm{O}$ pada proses amonifikasi, nitrifikasi, dan denitrifikasi. Faktor tingkat kehilangan $\mathrm{N}$ dari pupuk Urea antara $60 \%$ sampai $80 \%$ pada lahan sawah, dan $40 \%$ sampai $60 \%$ pada lahan kering sehingga hanya sekitar $30 \%$ sampai $50 \%$ yang dapat digunakan oleh tanaman. Rendahnya efisiensi disebabkan juga oleh proses volatilisasi yang akan menyebabkan kehilangan $\mathrm{N}$ sampai $70 \%$.

Las dan Tim (2008) dalam Sumarno et al. (2009), mengemukakan bahwa sebanyak 73\% lahan pertanian di Indonesia memiliki kandungan bahan organik yang rendah (kurang dari 2\%). Padahal bahan organik sangat diperlukan untuk budidaya tanaman, sebagai contoh adalah pada tanaman padi. Seperti dikatakan Makarim dan Suhartatik (2006), bahwa pada pengujian PTT di beberapa wilayah di Indonesia, pemberian pupuk organik dapat menghemat penggunaan pupuk urea tanpa mengurangi produktivitas padi.

Dewasa ini dunia pertanian mengisyaratkan bahwa pertanian sebaiknya kembali ke alam (back to nature) untuk mengatasi berbagai problema di bidang pertanian dan lingkungan yang diakibatkan penggunaan bahan kimia yang terkandung dalam pupuk. Dikatakan Nuryani et al. (2010), bahwa sistem pertanian alternatif yang menggunakan teknologi masukan rendah (low input energy) diyakini mampu memelihara kesuburan tanah dan kelestarian lingkungan sekaligus dapat mempertahankan, bahkan meningkatkan produktivitas tanah. Hasil penelitiannya menunjukkan bahwa penambahan pupuk organik berfungsi menaikkan $\mathrm{pH}$ tanah, meningkatkan KPK dan ketersediaan N, P, dan K tanah. Selain itu meningkatkan serapan hara N, P, dan K serta hasil tanaman padi. Sistem pertanian terbaik adalah kombinasi pupuk organik dan anorganik (sistem pertanian semi organik).

Selanjutnya Nuryani et al. (2010), mengatakan bahwa sistem low input energy ini mengutamakan rotasi tanaman, menggunakan limbah tanaman, pupuk kandang dan pupuk hijau terutama kacangkacangan. Dengan demikian pupuk hijau menjadi salah satu alternatif untuk mengurangi penggunaan pupuk buatan (anorganik). Selain itu juga mengatasi kesulitan ketika dihadapkan pada kondisi dimana pupuk kandang sulit didapatkan.

Dikatakan Marsuni et al (2013), bahwa pemberian bahan organik seperti pupuk hijau dari famili leguminoceae, dapat memperbaiki sifat fisik tanah, menambah bahan organik, menambah nitrogen dan fosfor serta dapat memperbaiki kehidupan jasad renik. Selanjutnya dikatakan Hasibuan (2013), bahwa pemberian pupuk organik dapat meningkatkan hasil jagung manis.

Bahan jenis bahan organik yang bisa kita dapatkan, yaitu dari pupuk kandang, kompos, pupuk hijau, dll. Turi mini (Sesbania rostrata) merupakan salah satu jenis pupuk hijau yang akan menjadi penolong dalam mengatasi kelangkaan dan dampak buruk pupuk anorganik serta kelangkaan pupuk kandang. 
Sebetulnya di negara lain, Sesbania rostrata sudah lama dikenal. Rinaudo et al. (1983) dalam Haryanto et al. (2004), telah menunjukkan bahwa $S$. rostrata mampu memfiksasi $\mathrm{N}_{2}$ udara 5 sampai 10 kali lebih besar daripada legum lainnya, yaitu dapat memfiksasi $\mathrm{N}_{2}$ udara mencapai $270 \mathrm{~kg}$ $\mathrm{N} \mathrm{ha}^{-1}$.

Dikatakan Umme et al. (2020), bahwa turi mini adalah tanaman pupuk hijau polongan popular yang memperbaiki $\mathrm{N}_{2}$ atmosfer, meningkatkan kesehatan tanah dan meningkatkan hasil padi $9 \%$ sampai $11 \%$ dibandingkan dengan pupuk kimia. Latt et al. (2009) juga menyampaikan hal yang serupa, bahwa pupuk hijau $S$. rostrata yang telah diinokulasi batangnya, meningkatkan bahan kering dan bobot gabah kering secara nyata lebih daripada urea. Ini disebabkan pertumbuhan dan akumulasi nitrogen sangat tinggi pada perlakuan inokulasi batang S. rostrata pada percobaan pendahuluan.

Sesbania rostrata Brem atau turi mini adalah tanaman yang tergolong leguminoceae, mempunyai nodul pada akar juga pada batangnya. Nodul berisi bakteri Rhizobium yang dapat menambat $\mathrm{N}_{2}$ dari udara serta mampu mengubah sejumlah besar nitrogen atmosfer tersebut menjadi bentuk yang dapat digunakan untuk tanaman. Daya menambat $\mathrm{N}_{2}$ pada turi mini mencapai 4,7\% lebih besar daripada kacang tanah maupun kedelai, yaitu $56 \mathrm{~kg} \mathrm{ha}^{-1}$ sampai $150 \mathrm{~kg} \mathrm{ha}^{-1}$ (Balai Penelitian Tanah, 2020). Menurut Sajimin et al. (2010), turi mini menghasilkan nodul 5 sampai 10 kali lebih banyak daripada leguminoceae lainnya. Nilai gizi dengan kandungan PK 24\%, P $0,2 \%$ sampai $0,3 \%$, NDF $54,6 \%$, ADF $39,2 \%$.

Pertumbuhan turi mini sangat cepat sehingga menghasilkan biomasa yang tinggi $8 \mathrm{t} \mathrm{ha}^{-1}$ sampai $11 \mathrm{t} \mathrm{ha}^{-1}$ untuk dibenamkan ke dalam tanah (Echo community, 2019). Oleh karena itu sangat memungkinkan untuk digunakan sebagai pupuk hijau.
Kelebihan lain turi mini adalah meningkatkan efisiensi penyerapan $\mathrm{N}$ sampai $25 \%$, meningkatkan kandungan $\mathrm{N}$ tanah dan meningkatkan penyerapan $\mathrm{P}$ (Badan Penelitian Tanah, 2020). Demikian juga menurut Hanson (2005) dalam Effendy et al. (2020), peningkatan efisiensi penyerapan $\mathrm{N}$ mencapai $25 \%$ dan terjadi peningkatan kandungan $\mathrm{N}$ tanah serta peningkatan penyerapan $\mathrm{P}$ yang berpengaruh positif terhadap pertumbuhan dan produksi tanaman.

Sifat baik lainnya dari turi mini sebagai pupuk hijau adalah karena tanaman ini mudah terdekomposisi di dalam tanah (Rinaudo et al., 1983 dalam Haryanto et al. (2004). Pupuk hijau yang satu genus dengan Sesbania rostrata yaitu Sesbania aculeata ternyata dapat meningkatkan kepadatan akar dan hasil biji gandum yang ditanam setelah padi juga membantu meningkatkan sifat fisik tanah pada padi sawah.

\section{PUPUK HIJAU TURI MINI (Sesbania rostrata)}

Secara umum definisi pupuk hijau adalah pupuk organik yang berasal dari tanaman atau sisa panen. Menurut Sutanto (2002), tanaman pupuk hijau merupakan sumber pupuk yang dapat meningkatkan dan mempertahankan kesuburan tanah. Pemberiannya dengan cara memasukkan bahan yang belum terdekomposisi ke dalam tanah yang bertujuan untuk meningkatkan produktivitas lahan. Cara menggunakan pupuk hijau selain dengan membenamkannya waktu tanaman tersebut masih dalam kondisi masih hijau, bisa juga segera setelah dikomposkan.

Secara umum, tanaman pupuk hijau yang disarankan dalam symposium "Green Manure in Rice Farming" di IRRI pada tahun 1988 dalam Suhartatik (2010), adalah tanaman pupuk hijau yang memiliki 
keunggulan berumur pendek, cepat tumbuh, mampu menimbun hara dalam jumlah banyak, toleran terhadap naungan, kekeringan, dan genangan, adaptif terhadap ekologi yang luas, efisien dalam penggunaan air, kecepatan menimbun hara $\mathrm{N}$ tinggi, mudah dibenamkan, hasil biji tinggi, dan tahan terhadap hama dan penyakit.

Selanjutnya Rachman et al. (2006) dalam Suhartatik (2010), mengatakan bahwa tanaman pupuk hijau dari jenis leguminoceae memberikan kontribusi $\mathrm{N}$ cukup tinggi, diantaranya Sesbania rostrata yang dapat menghasilkan biomass kering sebanyak $3 \mathrm{t} \mathrm{ha}^{-1}$ dalam waktu 45 hari. Pembenaman pupuk hijau ke dalam tanah bisa dalam bentuk segar apabila $\mathrm{C} / \mathrm{N}$ rasio bahan tanaman yang digunakan relatif rendah.

Turi mini (Sesbania rostrata) merupakan tanaman tahunan umur pendek dari family leguminoceae dan sub family Papilionideae, nama lainnya adalah Rostrate sesbania (Inggris). Turi mini digunakan untuk pupuk hijau atau makanan ternak. Tingginya dapat mencapai $3 \mathrm{~m}$, mempunyai bunga majemuk yang mempunyai 12 sampai 24 daun kecil pada setiap tulang daunnya. Bunganya berwarna kuning, berbentuk bunga kupu-kupu sepanjang $15 \mathrm{~cm}$ sampai $22 \mathrm{~cm}$, polongnya mengandung biji berwarna coklat sebanyak kurang lebih 50 butir. Kulit biji cukup tebal, sehingga perlu scarifikasi untuk mempercepat perkecambahan, dapat dilakukan dengan merendam biji dalam air hangat. Perbanyakan dapat dilakukan dengan ratoon atau stek yang berasal dari tunas liar sekitar pohon (Echo Community, 2019; Hanson (2005) dalam Sajimin et al., 2010).

Syarat tumbuh tanaman turi mini adalah sebagai berikut: Ketinggian tempat dari dataran rendah sampai $1500 \mathrm{~m}$ di atas permukaan laut, curah hujan $1500 \mathrm{~mm}$ sampai $5000 \mathrm{~mm}$, temperatur berkisar antara $15^{\circ} \mathrm{C}$ sampai $35^{\circ} \mathrm{C}$, sensitif terhadap panjang hari, memerlukan panjang hari kurang daripada 12 jam untuk dapat berbunga. Tanaman ini lebih suka cahaya matahari penuh. Tipe tanah yang diinginkan relatif luas daya adaptasinya dan toleran terhadap tanah yang tergenang (Echo Community, 2019). Sehingga turi mini tumbuh baik di daerah rawa Kalimantan (Sajimin et al., 2010).

Demikian juga dikatakan Dreyfus dan Dommergues (1981) dalam Sajimin et al., (2010), bahwa turi mini merupakan jenis leguminoceae tropis yang hidupnya berkelompok pada air tergenang. Dengan demikian turi mini mempunyai keunggulan dari tanaman pupuk hijau yang lain misalnya Crotalaria juncea yang tidak tahan genangan dan tidak toleran terhadap salinitas tinggi (Mannetje, 2011 dalam Susanti et al., 2013).

Rauf et al. (1987) dalam Suhartatik (2010), menyatakan bahwa turi mini ( $S$. rostrata) merupakan tanaman semak yang dapat tumbuh pada ketinggian tempat $1200 \mathrm{~m}$ di atas permukaan laut di daerah tropis maupun sub tropis. Berbagai jenis tanah tempat tumbuhnya mulai dari yang bereaksi masam sampai dengan tanah alkalis.

Selain daya adaptasinya yang luas, kelebihan turi mini dari pupuk hijau kelompok legum lainnya adalah kemampuannya untuk membentuk nodul. Nodula pada legum lain hanya terdapat pada akar, sedangkan pada turi mini nodula terdapat pada akar maupun batang. Dikatakan Rinaudo et al. dalam Haryanto et al. (2004), bahwa turi mini (Sesbania rostrata) adalah tanaman legum yang memiliki nodul yang mengandung bakteri Rhizobium tidak hanya pada bagian akar tetapi juga pada bagian batangnya. Oleh karena itu tanaman tersebut mampu memfiksasi $\mathrm{N}$ udara 5 sampai 10 kali lebih besar daripada legum lainnya.

Arunin et al. (1988) dalam Suhartatik (2010), menyatakan bahwa $S$. rostrata mempunyai kemampuan menambat $\mathrm{N}$ dari udara hingga $200 \mathrm{~kg} \mathrm{ha}^{-1}$ dalam waktu 
50 hari. Dikemukan Saraswati et al. (1994) dalam Suhartatik (2010), dari nodul batang terdapat tiga isolat bakteri yang dikenal sebagai Azorizhobium caulinodans yang sangat spesifik pada $S$. rostrata.

Menurut Hanson (2005) dalam Effendy et al. (2020), kelebihan turi mini yang lain adalah dapat meningkatkan penyerapan nitrogen dan fosfor di dalam tanah. Peningkatan efisiensi penyerapan $\mathrm{N}$ mencapai $25 \%$ dan terjadi peningkatan kandungan $\mathrm{N}$ tanah dan penyerapan $\mathrm{P}$ yang berpengaruh positif terhadap pertumbuhan dan produksi tanaman.

Berbagai penelitian menunjukkan manfaat turi mini dalam bidang pertanian. Penelitian Haryanto et al. (2004), tentang pengaruh kombinasi dua jenis pupuk hijau dan urea terhadap produsi dan serapan $\mathrm{N}$ padi sawah, hasilnya menunjukkan bahwa pemberian turi mini yang ditambahkan pupuk Urea $100 \mathrm{~kg} \mathrm{ha}^{-1}$ dan ditambah Azolla menghasilkan gabah kering, serapan $\mathrm{N}$ total dalam gabah sama dengan pemberian pupuk Urea $200 \mathrm{~kg} \mathrm{ha}^{-1}$. Artinya penambahan turi mini dan Azolla meningkatkan efisiensi urea sebanyak $100 \mathrm{~kg} \mathrm{ha}^{-1}$.

Penelitian Susanti et al. (2013) tentang pengaruh bahan organik terhadap pertumbuhan dan hasil tanaman padi (Oryza sativa L.) varietas Inpari 13 sistem tanam jajar legowo, menunjukkan bahwa pemberian turi mini ( $S$. rostrata) $1,75 \mathrm{t} \mathrm{ha}^{-1}$ dikombinasikan dengan pupuk kandang sapi 7,2 $\mathrm{t} \mathrm{ha}^{-1}$ menghasilkan gabah kering $5,27 \mathrm{t} \mathrm{ha}^{-1}$ lebih tinggi dibandingkan dengan pemberian Crotalaria juncea $2 \mathrm{t} \mathrm{ha}^{-1}$ ditambah pupuk kandang sapi 7,2 $\mathrm{t} \mathrm{ha}^{-1}$ yang menghasilkan gabah kering $4,45 \mathrm{t} \mathrm{ha}^{-1}$, walaupun sedikit lebih rendah daripada pemberian pupuk anorganik (urea $250 \mathrm{~kg}$ $\mathrm{ha}^{-1}$, SP36 $60 \mathrm{~kg} \mathrm{ha}^{-1}$ dan $\mathrm{KCl} 50 \mathrm{~kg} \mathrm{ha}^{-1}$ ) yang menghasilkan gabah kering 6,14 t ha-1.

Selain itu turi mini akan memberikan kontribusi yang besar terhadap ketersediaan hara dalam tanah yang ditunjukkan dengan hasil analisis kandungan hara, yaitu mengandung $\mathrm{C}$ organik $27,53 \%$ dan lebih tinggi daripada $C$. juncea yang mengandung $18,73 \%$ serta pupuk kandang sapi hanya $10,33 \%$. Kandungan $\mathrm{N}$ total yang diberi turi mini 3,7\%, yang diberi $C$. juncea $5,85 \%$ dan yang diberi pupuk kandang sapi mengandung 10,33\%. Kandungan bahan organik turi mini $47,46 \%$, C. juncea $32,29 \%$ dan pupuk kandang hanya $17,61 \%$. Dengan kandungan hara seperti ini akan memberikan kontribusi hara pada masa tanam berikutnya.

Hasil penelitian Effendy et al. (2020), tentang pengurangan penggunaan pupuk urea melalui pemanfaatan tanaman turi mini (Sesbania rostrata) pada budidaya jagung manis, menunjukkan bahwa pemberian pupuk urea $25 \%$ dari dosis anjuran $(435 \mathrm{~kg}$ ha $^{-1}$ ) yang dikombinasikan dengan 3 batang turi mini menghasilkan tinggi tanaman dan jumlah daun jagung manis paling tinggi. Sedangkan bobot tongkol terbanyak terdapat pada pemberian pupuk urea 50\% dosis anjuran dikombinasikan dengan 2 batang turi mini. Jadi pemberian turi mini ini dapat mengurangi penggunaan pupuk urea pada jagung manis.

Sejalan yang dikatakan Hikmawati (2014), bahwa pemberian nitrogen dapat meningkatkan kandungan butir hijau daun yang mempunyai peranan penting dalam proses fotosintesis dan mempercepat pertumbuhan tanaman. Semakin besar pemberian nitrogen, semakin tinggi tanaman dan bobot kering tanaman semakin besar.

Penelitian Latt et al. (2009), tentang pengaruh pupuk hijau Sesbania rostrata terhadap pertumbuhan dan hasil padi, menunjukkan bahwa perlakuan pupuk hijau 2 dan 4 tanaman pot $^{-1}$ meningkatkan bobot bahan kering dan bobot gabah secara signifikan dibandingkan perlakuan urea 40 $\mathrm{kg} \mathrm{ha}^{-1}$ dan $80 \mathrm{~kg} \mathrm{ha}^{-1}$ maupun kontrol. Perlakuan pupuk hijau meningkatkan serapan $\mathrm{N}$ oleh tanaman. Artinya pemberian pupuk hijau dari kelompok legum 
menambah jumlah $\mathrm{N}$ tanah hasil fiksasi secara biologis. Penggunaan secara efektif biomass yang dihasilkan oleh nodula batang $S$. rostrata merupakan komponen yang mempunyai kemampuan mengelola hara secara terintegrasi untuk meningkatkan komponen hasil dan hasil padi per satuan luas.

Hasil penelitian aplikasi pupuk hijau Sesbania rostrata yang berumur 45 hari, dengan cara dibenamkan ke dalam tanah dan dikombinasikan dengan pemberian urea $130 \mathrm{~kg} \mathrm{ha}^{-1}$ pada tanah vertisol Ngawi, memberikan hasil gabah kering 4,6 $\mathrm{t} \mathrm{ha}^{-1}$. Biomass yang dihasilkan Sesbania rostrata sebanyak $2 \mathrm{~kg} \mathrm{ha}^{-1}$ adalah $12,5 \mathrm{t} \mathrm{ha}^{-1}$ dan mengandung $75 \mathrm{~kg} \mathrm{~N}, 5 \mathrm{~kg} \mathrm{P}$ dan $18 \mathrm{~kg} \mathrm{~K}$ (Balittanah, 2020).

\section{METODE APLIKASI PUPUK HIJAU TURI MINI (Sesbania rostrata)}

Turi mini (Sesbania rostrata) sebagai pupuk hijau dapat diaplikasikan dengan berbagai cara. Sebagai contoh pada tanaman padi adalah dengan menumbuhkan bersamaan dengan penanaman padi karena tanaman tersebut tahan terhadap genangan. Benih turi mini yang telah dibibitkan selama 25 hari ditanam diantara 4 rumpun tanaman padi. Kalau padi ditanam dengan jarak 25 $\mathrm{cm} \times 25 \mathrm{~cm}$, maka turi mini ditanam dengan jarak tanam $25 \mathrm{~cm} \times 50 \mathrm{~cm}$. Setelah berumur 45 hari, turi mini dicabut dan dicacah seukuran $5 \mathrm{~cm}$, kemudian dibenamkan diantara tanaman padi. Setiap 1 ha lahan sawah dapat dipanen sebanyak $12 \mathrm{t} \mathrm{ha}^{-1}$ sampai $17 \mathrm{t} \mathrm{ha}^{-1}$ biomass turi mini setara dengan $2 \mathrm{t}$ nitrogen (Balittanah, 2020).

Sebagaimana telah diungkapkan oleh Sutanto (2002), bahwa tanaman pupuk hijau merupakan sumber pupuk organik yang berperan dalam mempertahankan kandungan bahan organik dan kesuburan tanah. Pemberian pupuk hijau berarti memasukkan bahan yang belum terdekomposisi ke dalam tanah yang bertujuan meningkatkan produktivitas lahan. Pendapat yang sama telah dinyatakan bahwa pupuk hijau yaitu pupuk organik yang berasal dari tanaman atau berupa sisa panen. Bahan tanaman tersebut dapat dibenamkan pada waktu masih hijau (FFTC, 1975 dalam Rachman et al., 2006). Selanjutnya Rachman et al. (2006), mengatakan bahwa pembenaman pupuk hijau ke tanah dalam bentuk segar bila rasio $\mathrm{C} / \mathrm{N}$ bahan tanaman yang digunakan relatif rendah.

Pengalaman terdahulu Rauf et al. (1989) dalam Suhartatik (2010), adalah menanam $10 \mathrm{~kg} \mathrm{ha}^{-1}$ Sesbania rostrata pada lahan sawah di Maros, dengan cara disebar dalam barisan yang berjarak $40 \mathrm{~cm}$ antar barisan. Kemudian dipanen pada umur 45 hari dan menghasilkan $\mathrm{N} 74,0 \mathrm{~kg} \mathrm{ha}^{-1}$, P 9,3 $\mathrm{kg} \mathrm{ha-1}$, dan $\mathrm{K} 50,4 \mathrm{~kg} \mathrm{ha}^{-1}$. Semakin bertambah umur tanaman, semakin meningkat biomass $S$. rostrata. Sebaliknya kadar P dan $\mathrm{K}$ daun serta kadar N, P, dan K pada batang semakin menurun.

Namun menurut Suhartatik (2010), laju pertumbuhan tanaman $S$. rostrata di tanah Latosol (Kebun Percobaan Muara, Bogor) sangat lambat pada minggu pertama sampai ketiga, agak cepat pada minggu keempat sampai kelima dan cepat sekali pada minggu selanjutnya. Bobot basah total tanaman pada umur 7 minggu mencapai $24,3 \mathrm{~g} \mathrm{tan}^{-1}$, yaitu $17,2 \mathrm{~g}$ bobot daun dan 7,1 g bobot akar.

Penanaman S. rostrata dengan cara menyisipkannya pada tanaman padi yang ditanam jajar legowo dikembangkan dalam program PTT. Perbanyakan benihnya dilakukan pada tanah marginal dan pematang sawah (Suhartatik, 2010). Penanaman S. rostrata secara tumpangsari dengan padi sawah meningkatkan hasil padi $7,7 \%$ sampai 22,6\% (Suhartatik et al. 1994 dalam Suhartatik (2010). 
Secara umum pemberian pupuk hijau pada tanah dapat dilakukan setelah pupuk tersebut didekomposisikan. Tujuannya adalah supaya unsur hara tersedia bagi tanaman pada saat tanaman membutuhkan. Namun turi mini (Sesbania rostrata) ini merupakan pupuk hijau yang mempunyai sifat mudah terdekomposi seperti dikatakan Rinaudo et al. (1983) dalam Haryanto et al. (2004). Dengan demikian tidak perlu didekomposisi secara khusus.

\section{SIMPULAN}

1. Turi mini (Sesbania rostrata) merupakan tanaman pupuk hijau kelompok leguminoceae. Turi mini dibandingkan dengan legum lainnya adalah mempunyai kelebihan dalam menambat $\mathrm{N}_{2}$ udara karena mempunyai nodula batang selain nodula akar. Nodula tersebut bersimbiosis dengan Azorhizobium caulinodans.

2. Kelebihan lain adalah kemampuannya beradaptasi pada lahan tergenang, salinitas tinggi, dan tahan kekeringan.

3. Perannya dalam bidang pertanian adalah menyumbangkan nitrogen sehingga mengefisienkan penggunaan urea (pupuk kimia).

4. Aplikasi turi mini (Sesbania rostrata) yaitu dengan cara ditumpangsarikan dengan padi, jagung atau gandum dan dibenamkan dalam bentuk segar pada umur muda (45 hari).

\section{SARAN}

Penelitian yang dilakukan terhadap turi mini pada umumnya untuk menambah unsur hara pada tanaman padi dan palawija. Sehingga penulis menyarankan melakukan telaah pada tanaman lain misalnya sayuran dan tanaman hias.

\section{DAFTAR PUSTAKA}

Abdurachman, S., Susanti, Z., \& Suhana. (2004). Efisiensi penggunaan pupuk pada tanaman padi selama dua musim berturut-turut. Penelitian Pertanian, 23(2): 65-72.

Balai Penelitian Tanah. (2020). Turi mini Sesbania rostrata dan Azolla dapat mensubstitusi sebagian pupuk nitrogen. Balittanah.litbang.pertanian.go.id $>\mathrm{i}$ nd>index.php>301-nitro. Diakses 02 Agustus 2020.

Echo community. Sesbania. (2019). Echocommunity.org/id/resources/17 1a5040-bc48-48d6-aebd-0cf49e6e714e. Diakses 2020.

Effendy, Iqbal, Palman, \& Marlina N. (2020). Pengurangan penggunaan pupuk urea melalui pemanfaatan tanaman turi mini (Sesbania rostrata) pada budidaya jagung manis. Vegetalika, 9(2): 425-436.

Hapsari, R.I. (2011). Pertumbuhan dan hasil padi (Oryza sativa L.) varietas Ciherang yang ditanam pada kombinasi macam dan dosis bahan organik. Thesis. S-2 Program Pascasarjana Universitas Brawijaya. Malang.

Haryanto, Idawati, Havid R., \& Sisworo E.L. (2004). Pengaruh kombinasi dua jenis pupuk hijau dan urea terhadap produksi dan serapan $\mathrm{N}$ padi sawah. Risalah seminar ilmiah penelitian dan pengembangan aplikasi isotop dan radiasi. Puslitbang Teknologi Isotop dan Radiasi. BATAN. Jakarta, 17-18 Februari 2004.

Hasibuan, S. (2013). Tanggap pertumbuhan dan produksi tanaman jagung manis (Zea mays saccharata Sturt L) terhadap pemberian pupuk limbah cair pabrik kelapa sawit dan pupuk TSP. J. Penelitian Pertanian BERNAS, 8(3): 38-42. 
Hidayati, E., \& Armaini. (2015). Aplikasi limbah cair biogas sebagai pupuk organik pada tanaman jagung manis (Zea mays saccharata Sturt). JOM Faperta, 1(12): 1-14.

Hikmawati, M. (2014). Pengaruh varietas dan penggunaan dosis pupuk terhadap produksi jagung (Zea mays L.). Jurnal Media Soerjo, 14(1): $70-84$.

Latt, Y.K., Myint, A.K., Yamakawa T., \& Ogata, K. (2009). The effects of green manure (Sesbania rostrata) on the growth and yield of rice. Journal of The Faculty of Agriculture Kyushu University, 54(2): 313-319. https://catalog.lib.kyushuu.ac.jp/opac_download_md/16109/ 54_2_p313.pdf. Diakses 29 Juli 2020.

Makarim, A.K., \& E. Suhartatik. (2006). Budidaya padi dengan masukan in situ menuju perpadian masa depan. Buletin Iptek Tanaman Pangan, 1(1): 19-29.

Marsuni, Z., Subaedah, St., \& Koes, F. (2013). Keragaan pertumbuhan jagung dengan pemberian pupuk hijau disertai pemupukan $\mathrm{N}$ dan $\mathrm{P}$. Prosiding Seminar Nasional Serealia, "Meningkatkan peran penelitian serealia menuju pertanian bioindustri", pp 244-251. Maros, 18 Juni 2013.

Mathuika, R.K., Chaudhary, R.P., Shivran, A., \& Bhosale, N. (2014). Response of Rabbi Sweet Corn to plant geometry and fertilizer. Curren Biotica, 7(4): 294-298.

Nuryani, Sri H.U., Haji M., \& Widya N.Y. (2010). Serapan Hara N, P, K pada tanaman padi dengan berbagai lama penggunaan pupuk organik pada vertisol Sragen. Jurnal Ilmu Tanah dan Lingkungan, 10(1): 1-13.

Sajimin, Purwantari, N.D., \& Sutedi, E. (2010). Karakterisasi turi mini
(Sesbania rostrata) sebagai pakan ternak kerbau rawa di Kalimantan Selatan. Seminar dan Lokakarya Nasional Kerbau, "Percepatan perbibitan dan pengembangan kerbau melalui kearifan lokal dan inovasi teknologi untuk mensukseskan swasembada daging kerbau dan sapi serta peningkatan kesejahteraan masyarakat peternak". pp 101-106. Balai Penelitian Ternak.

Simanungkalit, R.D.M. (2006). Prospek pupuk organik dan pupuk hayati di Indonesia. Dalam Simanungkalit, R.D.M., et al. Pupuk organik dan pupuk hayati pp. 265-271. Bogor: Balai Besar Litbang Sumber Daya Lahan Pertanian.

Suhartatik, E. (2010). Prospek Sesbania rostrata sebagai pupuk hijau pada padi sawah. Balai Besar Penelitian Tanaman Padi. Iptek Tanaman Pangan, 5(1): 15-30.

Sumarno, I.G., Ismail, \& Partohardjono, S. (2000). Konsep Usahatani ramah lingkungan. Dalam A. Karim Makarim et al. (Eds). Tonggak kemajuan teknologi produksi tanaman pangan. pp 55-74. Bogor: Pusat Penelitian dan Pengembangan Tanaman Pangan.

Sumarno, U.G., Kartasasmita, \& Pasaribu D. (2009). Pengayaan kandungan bahan organik tanah mendukung keberlanjutan system produksi padi sawah. Buletin Iptek Tanaman Pangan, 4(1):18-32.

Susanti, R.A., Sumarni, T., \& Widaryanto E. (2013). Pengaruh bahan organik terhadap pertumbuhan dan hasil tanaman padi (Oryza sativa L.) varietas inpari 13 sistem tanam jajar legowo. Jurnal Produksi Tanaman, 1(5): 456-463.

Sutanto, R. (2002). Pertanian organik. Yogyakarta : Kanisius. 
Suwardi \& Efendi, R. (2009). Efisiensi penggunaan pupuk $\mathrm{N}$ pada jagung komposit menggunakan bagan warna daun. Prosiding Seminar Nasional Serealia. "Inovasi teknologi serealia menuju kemandirian pangan dan agroindustry”. pp 108-115. Balai Penelitian Tanaman Serealia.

Umme, A. Naher, Choudhury, A.T.M.A., Biswas, J.C., Panhwar, Q.A., \& Kennedy, I.R. (2020). Prospect of using leguminous green manuring crop Sesbania rostrate for supplementing fertilizer nitrogen in rice production and control of environmental pollution. Journal of Plant Nutrition, 43(2): 285-296.

Vanyine, A.S., Toth B., \& Nagy J. (2012). Effect of nitrogen doses on the chlorophyll concentration, yield and protein content of different genotype maize hybrids in Hungary. African Journal of Agricultural Research, 7(16): 2546-2552.

Wahid, A.S. (2003). Peningkatan efisiensi puuk nitrogen pada padi sawah dengan metode bagan warna daun. Jurnal Litbang Pertanian, 22(4): 156-161. 